\title{
EVALUATION OF THE PLANNING, IMPLEMENTING, AND MONITORING OF THE URBAN FOREST IN RECIFE, PERNAMBUCO, BRAZIL
}

\author{
by Isabelle Maria Jacqueline Meunier, José Antônio Aleixo da Silva, and \\ Crueza Maria dos Santos
}

\begin{abstract}
Techniques for planning, implementing, and monitoring urban forest management in the Municipal Department of Recife, Brazil, were analyzed. During two months in 1996, planting and pruning programs were also evaluated. We observed an absence of planning and a failure to employ technical approaches in species selection, installation, and pruning. We identified such problems as planting trees of medium size under power lines, use of saplings of poor form, insufficient space for the growth of the trees, lack of fertilization and other cultural treatments, inadequate pruning, and inefficient systems for follow-up monitoring and evaluation. An urban forest management plan was recommended to the city.
\end{abstract}

The city of Recife, capital of the state of Pernambuco, is in the northeast area of Brazil, along the Atlantic Ocean. It has a population of $1,311,327$ and an area of $223 \mathrm{~km}^{2}\left(80.4 \mathrm{mi}^{2}\right)$ (Sette 1987). Recife's natural vegetation and terrain are influenced by the estuary and tidal environment. Besides the area of the low estuary, there is a flood plain of approximately $53 \mathrm{~km}^{2}$ $\left(19.2 \mathrm{mi}^{2}\right)$, where the old sandbank vegetation was initially converted to sugar-cane plantations and later to urban neighborhoods.

Surrounding the plain area is a group of hills, originally covered by the coastal tropical rain forest. Since the Portuguese colonization in the 16th century, this area has been intensely deforested and is now a densely populated urban area.

Over its 440-year history, Recife's natural and cultural characteristics have been altered significantly. The main environmental changes were deforestation and draining of swamps, inadequate solid-waste disposal, water pollution from inadequate waste treatment, erosion of deforested hillsides, and poor conservation of natural resources.

The urban forest can be defined as the trees, natural or cultivated, within a city (Sanchotene 1994). It includes trees on public streets and roads, in parks, squares, gardens, private areas, and the residual native forest. Each component has a role in the improvement of environmental quality of urban centers and, in the same way, each demands management practices as well as monitoring and conservation.

Being an old city with haphazard planning and the destination of immigrants from the northeast, Recife has a high growth rate in population and real estate development, which results in significant problems for the urban forest. For example, small gardens and residential back yards are giving way to large buildings. Areas of native vegetation on the periphery of Recife are subject to development through real estate speculation and the construction of residences. Street tree planting is often carried out haphazardly, without considering the space and maintenance requirements of trees. To avoid or reduce these problems, Recife requires a comprehensive urban forest management plan for the selection, planting, and care of new trees, as well as for the conservation of native forests.

The goals of this study were to evaluate the planning practices and to monitor trees on the streets, roads, and squares of Recife, as well as to identify urban forest management problems and suggest some solutions. We monitored the activities of the Division of Pruning and Plantation (DVPP), which is the department responsible for maintenance.

\section{Environmental and Historical Aspects}

The city of Recife is located on the coast in the northeast of Brazil, in the state of Pernambuco, at $8^{\circ}$ south latitude and $34^{\circ} 55^{\prime}$ west longitude. The climate is hot and humid, with an average temperature of $26^{\circ} \mathrm{C}\left(79^{\circ} \mathrm{F}\right)$, with a maximum of $33^{\circ} \mathrm{C}$ $\left(91^{\circ} \mathrm{F}\right)$ and a minimum of $19^{\circ} \mathrm{C}\left(66^{\circ} \mathrm{F}\right)$, and annual precipitation of $1,700 \mathrm{~mm}$ (70 in.) (Sette 1987). 
Founded in 1537, at the beginning of the Portuguese colonization, Recife was the "port of the ships," where sugar produced at the mills of Pernambuco was shipped and where slaves from Africa arrived, as well as a wide range of valuable products. In 1630, the period of Dutch dominion began in Pernambuco. After initial conquest, the Count Maurício de Nassau arrived, representing the Indian Westerners' Company. Nassau built Maurícia City as the capital of Dutch Brazil, endowing it with palaces, parks, and wide streets after Dutch designs, in what is now the central neighborhoods of Recife. This was probably the first time that native and exotic plants were used in the urban forests of Brazilian cities. Historical reports and iconography of the time reveal some aspects of the extensive gardens and boulevards, such as the Palace of Friburgo or the Towers, where 300 transplanted adult coconut trees were planted. In addition, tropical fruit trees of American, Asian, and African origin were planted (Andrade 1995). Nassau left Recife in 1644 and the Dutch were expelled from Pernambuco in 1654. The beautiful landscape created by Maurício de Nassau was subsequently lost.

By 1709 , the settlement pattern of Recife focused on villas. During the 18th century, the urban forest consisted mainly of vegetation on ranches, known as brushwood. With the expansion of the city, the brushwood retreated. The suburbs emerged as residences for families who surrounded their homes with great back yards, rich in fruit trees.

In 1823, the community of Recife was elevated to the city category. It was also in the 19th century that there were initial plantings of gameleiras (Chorisia speciosa) in the streets and squares. The city government oversaw management of the trees and invited inhabitants to plant more trees, including the native species aroeira (Schinus terebinthifolia), white or red gameleira (Chorisia speciosa), espinho-de-judeu (Xylosma salzmanii), trapiá (Crateva benthami), visgueiro (Parkia pendula), caneleira (Ocotea gardneri), and the exotic fruit tree mangueira (Mangifera indica) (Sette, no date).

Today, the older neighborhoods of Recife contain elements of these original plantings, with many trees that date from the early 20th century. However, over time, the urban plan of Recife changed with growth of the city. The urban forest today exists among the typical problems of large cities. Thus, the management of this urban forest requires an efficient system of assessment and maintenance.

Although the importance of the urban forest is known and emphasized by many authors, there are few studies of the urban forest of Recife. Among them are the evaluation of the urban forest by Biondi (1985) and the proposal of Veras (1985), which consist of an urban forest survey and development of a management plan for the municipal district. Beginning in 1993, the city government of Recife initiated an inventory of all the trees of public streets and roads using a geographical information system (GIS) (Freire 1994).

\section{Material and Methods}

To evaluate the current planning program and management of the urban forest in Recife, we considered three aspects: an evaluation of requests for new plantings, an evaluation of the technical aspects of the plantings, and evaluation of pruning practices.

Evaluation of requests for new plantings. For 60 days, from May to June 1996, all requests from citizens for planting were registered, including date and location of the planting and number of trees planted by species.

Evaluation of technical aspects of plantings. For plantings in public streets and roads, we took a random sample of 16 requests and identified the date of the request, the location of the requested planting (address), the type of the site (residence, residential condominium, school, industry, business, square, margins of galleries, etc.), the species to be planted, the date of planting, and the conditions of the planting (sapling height, stacking protection, presence and height of power lines, distance from the curb, free area for basal development, and distance to the buildings). We evaluated the standard planting methods, comparing them with those suggested by the specialized literature (CESP 1988). For plantings in squares, we evaluated recent plantings in four public squares, analyzing spe- 
cies performance, sapling quality, and the resulting effects of the plantings.

Evaluation of pruning practices. We evaluated three operations of pruning, for a total of 44 trees. For each operation, we assessed the date, street, neighborhood, skill of the work team, equipment used, and level of care taken by workers. Each pruned tree was evaluated for its pruning needs, quality of the work, occurrence and types of damages, and condition of the tree after pruning.

\section{Results and Discussion}

Handling of planting requests for public streets and roads. Requests for tree planting were made by citizens through phone calls to Recife's Municipal Department of Urban Forestry. Most of the solicitations came from owners of houses and condominiums, as well as from associations and schools. In the study period, 123 requests for tree plantings were registered. In response, 335 saplings of 16 species of trees and shrubs were planted (Table 1).

Of the species used, cássia amarela (Senna siamea), sombreiro (Clitoria fairchildiana), and espirradeira (Nerium oleander) represented $72.8 \%$ of total. The predominance of Senna siamea in the urban forest of Recife has been mentioned by Biondi (1990). Other species listed as common in 1985 were oiti-da-praia (Licania tomentosa), amendoeira (Terminalia catappa), algaroba (Prosopis juliflora), ficus (Ficus microcarpa), flamboyant (Delonix regia), and acácia mimosa (Pithecelobium dulce). These species are no longer planted. On the other hand species such as palm (Elaeis guineensis), Cuban acacia (Thespesia populnea), and jasmimde-natal (Lagerstroemia indica) were used. These last two species are of small and medium size and can be planted under the power lines.

The choice of the species to be planted was based on the applicants' desires and the availability of saplings. This procedure did not take into account the species existing in the area or the real needs of the sites.

Evaluation of technical aspects of new plantings in public roads and squares. The elapsed time from request to actual planting varied from one day to three months. The planted
Table 1. Number of saplings planted in public streets and roads, by species, from May to June 1996.

\begin{tabular}{|c|c|c|}
\hline $\begin{array}{l}\text { Common name/ } \\
\text { species }\end{array}$ & $\begin{array}{l}\text { No. } \\
\text { of trees }\end{array}$ & $\%$ \\
\hline $\begin{array}{l}\text { Cássia amarela } \\
\text { (Senna siamea) }\end{array}$ & 132 & 39.4 \\
\hline Sombreiro & & \\
\hline $\begin{array}{l}\text { (Clitoria fairchildiana) } \\
\text { Espirradeira }\end{array}$ & 57 & 17.0 \\
\hline (Nerium oleander) & 55 & 16.4 \\
\hline $\begin{array}{l}\text { Palmeira dendê } \\
\text { (Elaeis guineensis) }\end{array}$ & 21 & 6.3 \\
\hline $\begin{array}{l}\text { Felício } \\
\text { (Felicium decipiens) }\end{array}$ & 20 & 6.0 \\
\hline $\begin{array}{l}\text { Acácia cubana } \\
\text { (Thespesia populnea) }\end{array}$ & 17 & 5.0 \\
\hline $\begin{array}{l}\text { Pau-brasil } \\
\text { (Caesalpinia echinata) }\end{array}$ & 8 & 2.4 \\
\hline $\begin{array}{l}\text { Algodâo-da-praia } \\
\text { (Hybiscus pernambucensis) }\end{array}$ & 7 & 2.1 \\
\hline $\begin{array}{l}\text { Jasmim-natal } \\
\text { (Lagerstroemia indica) }\end{array}$ & 5 & 15 \\
\hline Mororó & & 1.0 \\
\hline $\begin{array}{l}\text { (Bauhinia variegata) } \\
\text { Palmeira imperial }\end{array}$ & 4 & 1.2 \\
\hline $\begin{array}{l}\text { Palmeira imperial } \\
\text { (Roystone regia) }\end{array}$ & 3 & 0.9 \\
\hline $\begin{array}{l}\text { Espatódea } \\
\text { (Spathodea campanulata) }\end{array}$ & 2 & 0.6 \\
\hline $\begin{array}{l}\text { Cássia-cordão-de-ouro } \\
\text { (Cassia fistula) }\end{array}$ & 1 & 0.3 \\
\hline $\begin{array}{l}\text { Cássia rosa } \\
\text { (Cassia rosea) }\end{array}$ & 1 & 0.3 \\
\hline $\begin{array}{l}\text { Sibipiruma } \\
\text { (Caesalpinia peltophoroides) }\end{array}$ & 1 & 0.3 \\
\hline $\begin{array}{l}\text { Ipê roxo } \\
\text { (Tabebuia spp.) }\end{array}$ & 1 & 0.3 \\
\hline Total & 335 & 100.0 \\
\hline
\end{tabular}

trees were of species suggested by the applicants, the most common being Senna siamea.

In the evaluated plantings, planted saplings were of the recommended height (above $1.8 \mathrm{~m}$ [6 ft]) in only two locations. Most of the saplings were 0.8 to $1.5 \mathrm{~m}(2.5$ to $5 \mathrm{ft})$, with heights of $0.3 \mathrm{~m}(1 \mathrm{ft})$ in a few locations. The saplings used in the plantings were produced in plastic bags of sizes varying from $12 \times 15 \mathrm{~cm}$ to $20 \times 30 \mathrm{~cm}$ $(4.5 \times 6$ in. to $8 \times 12$ in.) at the nursery of the city's Municipal Department. All the saplings received protection frames and support. Planting pits varied in size. No fertilizer was added at plant- 
ing. The saplings were planted at distances from the curb that ranged from 0.1 to $0.8 \mathrm{~m}(0.3$ to $2.5 \mathrm{ft})$. In $80 \%$ of the plantings, free areas were maintained for the basal area growth of $0.25 \mathrm{~m}^{2}$ $\left(2.7 \mathrm{ft}^{2}\right)$, which is below the technical recommendation of $1 \mathrm{~m}^{2}\left(11 \mathrm{ft}^{2}\right)$ (CESP 1988). In $50 \%$ of the locations, phone wires and power lines were located $5 \mathrm{~m}(16.4 \mathrm{ft})$ above saplings. In those places, trees of medium size with great crown volume were installed; these trees will require future pruning. The distance from the trees to buildings varied from 0.6 to $3 \mathrm{~m}$ ( 2 to $10 \mathrm{ft}$ ).

From May to June 1996, 544 trees and shrubs were planted in squares of Recife. In the four evaluated squares, spacing between trees was $2 \mathrm{~m}(6.5 \mathrm{ft})$, resulting in excessive density. The species commonly used in the squares were Tamarindus indica, Cassia grandis, Delonix regia, Spatodea campanulata, and several palm species, with a prominence of the dendê (Elaeis guineensis), and other ornamental trees.

Analysis of pruning practice. The pruning operation team included of six to eight workers who used machetes to cut the branches. Only one team used safety equipment, such as gloves and protection glasses. In no case was sanitization used. The average pruning time varied from 15 to 20 minutes per tree. The species pruned in the three pruning operations are listed in the Table 2.

The largest number of pruned trees was for Pithecelobium dulce, a species of great size with an irregular trunk and crown. Of the observed work, $86.4 \%$ was considered advisable and $2.3 \%$ indispensable (related to power lines). It was determined that $11.4 \%$ of the trees were pruned unnecessarily. The quality of pruning was considered poor in $4.5 \%$ of the cases, acceptable in $93.2 \%$, and good in $2.3 \%$.

On the 44 trees pruned, $84.1 \%$ suffered light damage from the pruning. The most frequent injuries were scars $(72.1 \%)$ and deformed or unbalanced crowns (27.9\%). The high frequency of damaged trees was due the lack of technical supervision, lack of training of the operators, and the use of inadequate equipment. On the pruned trees, $25 \%$ required additional pruning work and $4.5 \%$ were considered unrecoverable.
Table 2. Trees pruned, by species.

\begin{tabular}{llr}
\hline $\begin{array}{l}\text { Common name/ } \\
\text { species }\end{array}$ & \multicolumn{1}{l}{$\begin{array}{l}\text { No. } \\
\text { of trees }\end{array}$} & $\%$ \\
\hline $\begin{array}{l}\text { Acácia-mimosa } \\
\text { (Pithecelobium dulce) }\end{array}$ & 16 & 36.4 \\
$\begin{array}{l}\text { Oitizeiro } \\
\quad \text { (Licania tomentosa) }\end{array}$ & 11 & 25.0 \\
$\begin{array}{l}\text { Cássia siamea } \\
\text { (Senna siamea) }\end{array}$ & 10 & 22.7 \\
$\begin{array}{l}\text { Amendoeira } \\
\quad \text { (Terminalia catappa) }\end{array}$ & 03 & 6.8 \\
$\begin{array}{l}\text { Sombreiro } \\
\text { (Clitoria fairchildiana) }\end{array}$ & 02 & 4.5 \\
$\begin{array}{l}\text { Ficus benjamim } \\
\quad \text { (Ficus microcarpa) }\end{array}$ & 01 & 2.3 \\
$\begin{array}{l}\text { Ipê roxo } \\
\text { (Tabebuia spp.) }\end{array}$ & 01 & 2.3 \\
Total & 44 & 100.0 \\
\hline
\end{tabular}

\section{Conclusions}

The Municipal Department of Recife, which is responsible for the urban forest, does not have a comprehensive management plan. There is neither planning of new plantings nor monitoring of the existing urban forest. The city lacks the ability to advance and to recommend tree species, planting times, and cultural treatments. In spite of the potential for diversity, recent plantings incorporate little species variation. There is little use of native species with good performance potential, such as Tabebuia spp.

One of the most significant limitations to tree growth in Recife is the presence of overhead power lines along the streets. Species with otherwise good potential for use as street trees cannot be planted because they will interfere with the utility wires. In the last ten years, no new plantings of traditional species such as Licania tomentosa, Terminalia catappa, Ficus microcarpa, and Delonix regia have been implemented.

In response to citizen requests, species selection did not take into consideration important site factors such as width of the street and sidewalk, height of the power lines, soil conditions, or type and intensity of the traffic. Requests for tree plantings were from traditional neighborhoods of Recife, most of them middle class, and the goal was to restore or enlarge the existing 
urban forest. There were no requests for plantings in recently urbanized areas.

The plantings in public streets and roads used stocks of small height and poor quality without enough area for sufficient basal growth. Trees of medium size (height above $6 \mathrm{~m}$ [20 ft]) were installed under the power lines and too close to buildings. There was little or no supplementary fertilization, irrigation, weeding, or pest control.

The revival of public squares involved the largest number of new trees, although planting did not follow a project or consider the original design of each square. The intensive planting did not seem to be a landscaping decision but rather a management option to compensate for the lack of trees along the public streets and roads.

As observed in our study, pruning damaged the trees, causing wounds and unbalanced crowns. The use of the machetes was considered inappropriate; saws or similar equipment should be used. The pruning operations also revealed a lack of training and technical supervision. This caused problems in worker safety, a lack of good pruning technique, and a distortion of tree form and structure. The monitoring system adopted by the Municipal Department was ineffective because it was based on registration of new plantings and completed pruning, without an effective method for evaluating the quality of the work.

We recommend that the Division of Pruning and Plantation of the City of Recife, as well as agencies providing similar services in another cities, immediately prepare and implement a comprehensive urban forest management plan, including:

- a system of data collection and evaluation for the urban forest

- a plan for new planting and cultural treatments based upon species and site requirements

- technical norms for species selection, production, evaluation, size of pits, fertilization, distance from the curb, buildings, and power lines, free area at the base, types of frame protection, irrigation, pruning, pest management, and replanting

- training of technical and support staff
- education of the population about conservation of the urban forest, as part of a systematic program of environmental education

- technical norms for the pruning, for the municipal department as well as for electric and telephone companies

- management programs for other parts of the urban forest, which should include new areas, preservation of parks and areas of native vegetation, revival of squares considering their historical and cultural values, and motivations for the planting of trees in back yards and ranches

- creation of a research nucleus of support to study potential species, with emphasis on native trees.

\section{Literature Cited}

Andrade, M.C. 1995. Pernambuco imortal. J. Commercio. Recife. 2:3-14.

Biondi, D. 1985. Diagnóstico da arborização urbana da cidade do Recife. Universidade Federal do Paraná, Curitiba. 164 pp.

Biondi, D. 1990. Situação da arborização das áreas verdes da cidade do Recife, pp 27-30. In Proceedings of the 2nd Brazilian Congress of Urban Forest. Brazil

CESP. 1988. Guia de arborização. São Paulo. 13 pp.

Freire, F. J. 1994. Cadastramento das árvores públicas da cidade do Recife utilizando o sistema de informações geográficas (GIS), pp 431-445. In Proceedings of the 2nd National Meeting of Urban Forest. Brazil.

Sanchotene, M.C. 1994. Desenvolvimento e perspectiva da arborização urbana no Brasil, pp 15-25. In Proceedings of the 2 nd National Meeting of Urban Forest. Brazil.

Sette, M. (no date). História pitoresca do Recife antigo. Casa do Estudante do Brasil. Rio de Janeiro. $368 \mathrm{pp}$.

Sette, D.N. 1987. Guia pernambucano. Raiz. Recife. pp. 38-39.

Veras, L.M.S.C. 1985. Plano de arborização de cidades: Metodologia. PCR. Recife. 77 pp. 
Departamento de Ciência Florestal

Universidade Federal Rural de Pernambuca (UFRPE)

\author{
Av. D. Manual de Medeiros s/n Dois Irmãos \\ Recife \\ Pernambuco \\ CEP 52171-030 BRAZIL
}

Résumé. Les techniques de l'organisation et conduction adoptées par le service municipal de l'arborization urbain de Recife ont étées évaluées. Pendant deux mois, dans 1996, les plantations et les opérations de tailles accomplies ont aussi étées évaluées. Il a été observé l'absence des actions de l'organisation et aucune adoption d'approches techniques à propos de la sélection d'espèce et réalisation de plantations et tailles. Il a été identifié des problèmes comme plantations d'arbres de dimension moyenne sous ligne à haute tension, plants de modèle inadéquat, espace insuffisant pour l'augmentation des arbres, absence de assaisonnement et traitements culturels, tailles inadéquates et systèmes inefficaces d'écoute et évaluation. Á la fin, un plan de l'arborization a été recommandé.
Zusammenfassung. Die Planung, Ausführung und Überwachung von Stadtforstprogrammen in Recife, Brasilien wurden hier analysiert. Über eine Zeitraum von zwei Monaten wurden auch die Pflanzungen und Baumschnittmaßnahmen bewertet. Es gibt einen Mangel bei der Planung und bezüglich der Artenauswahl, Pflanzung und Schnittausführung wurden keine geeigneten Techniken angewendet. Polgende Probleme wurden identifiziert: Pflanzung von mittelwüchsigen Bäumen unter Versorgungslinien, Pflanzenmaterial von minderer Qualität, zu kleine Pflanzlöcher, schlechte Schnittführung und uneffiziente Systeme der Überwachung und Bewertung. Am Ende wird ein Plan für einen Stadtforst vorgestellt.

Resumen. Se analizó la planeación, implementación y monitoreo del programa de Dasonomía Urbana de Recife, Brasil. La plantación y las operaciones de poda también fueron evaluadas por un período de dos meses. Hubo ausencia de planeación y aplicación de tecnologías apropiadas en lo concerniente a la selección de las especies, plantación y poda. Los problemas identificados incluyen plantación de árboles de tamaño mediano bajo líneas eléctricas, pobre calidad de las existencias para la plantación, espacio insuficiente para el crecimiento de los árboles, ausencia de fertilización y tratamientos culturales, poda inapropiada y sistemas ineficaces de monitoreo y evaluación. Al final se recomendó un plan de dasonomía urbana. 